\title{
ANALISIS YURIDIS TINDAK PIDANA PEMALSUAN AKTE CERAI
}

\author{
Oleh
}

Sukhebi Mofea dan Ahmad Fuad Jaelani*)

\section{Abstrak}

Pernikahan adalah salah satu asas pokok hidup yang paling utama dalam pergaulan atau masyarakat yang sempurna. "Annikahu Sunnaty paman rogiba an sunnaty falaisa minni" Rasullalah saw bersabda.pernikahan bukan saja merupakan satu jalan yang amat mulia untuk mengatur kehidupan rumah tangga dan keturunan, tetapi juga dapat dipandang sebagai satu jalan menuju pintu perkenalan antara suatu kaum dengan kaum lain, dan perkenalan itu akan menjadi jalan untuk menyampaikan pertolongan antara satu dengan yang lainnya. Pemalsuan terhadap sesuatu merupakan salah satu bentuk tindak pidana yang telah diatur dalam kitab undang-undang hukum pidana (KUHP). Memang pemalsuan sendiri akan mengakibatkan seseorang atau pihak yang merasa dirugikan. Hal inilah yang membuat pemalsuan ini diatur dan termasuk suatu tindakan pidana.

\section{Kata Kunci : Pemalsuan, Akte Cerai, Tindak Pidana}

\section{A. PENDAHULUAN}

Pernikahan adalah salah satu asas pokok hidup yang paling utama dalam pergaulan atau masyarakat yang sempurna. "Annikahu sunnaty paman rogiba an sunnaty falaisa minny" Rasullah saw bersabda :

"nikah itu adalah sunahku barang siapa yang tidak mengikuti sunnahku berarti ia bukan golonganku".

Pernikahan bukan saja merupakan satu jalan yang amat mulia untuk mengatur kehidupan rumah tangga dan keturunan, tetapi juga dapat dipandang sebagai satu jalan menuju pintu perkenalan antara suatu kaum dengan kaum lain, dan perkenalan itu akan menjadi jalan untuk menyampai-

*) Penulis adalah Dosen Fakultas Hukum Universitas Islam Syekh Yusuf kan pertolongan antara satu dengan yang lainnya. ${ }^{1}$

Hukum perkawinan yang berlaku bagi tiap-tiap agama tentu memiliki perbedaan, akan tetapi tidak saling bertentangan. Di Indonesia telah ada hukum perkawinan yang secara otentik diatur dalam UndangUndang No. 1 Tahun 1974 Lembaran Negara RI.

Untuk Negara yang menjunjung tinggi nilai-nilai adat dan kesakralannya, mutlak adanya Undang-Undang perkawinan Nasional yang sekaligus menampung prinsip-prinsip dan memberikan landasan hukum perkawinan yang selama ini menjadi pegangan dan telah berlaku bagi golongan masyarakat Indonesia. ${ }^{2}$

1 Tarmizi M. Jakfar, Poligami dan Talak Liar dalamPerfpektif Hakim Agama di Indonesia Banda Aceh :Ar-Raniry Press, 2007

2 Sudarsono, HukumPerkawinan Nasional, RinekaCipta, Jakarta, 2010 hlm.6 
Kebanyakan seorang wanita tidak menghendaki suaminya mempunyai wanita lain dalam kehidupan rumah tangganya. Undang-Undang melindungi hak wanita tersebut di dalam Pasal 3 Ayat (2) Undang-Undang No. 1 Tahun 1974.

Dimana dicantumkan bahwa pengadilan dapat memberikan izin kepada seorang suami apabila dikehendaki oleh pihak-pihak yang bersangkutan. Di dalam Pasal 4 diatur bahwa seorang suami yang akan beristri lebih dari satu orang memiliki syarat apabila istri tidak dapat menjalankan kewajibannya, mendapat cacat badan atau penyakit yang tidak disembuhkan serta istri tidak dapat memiliki atau memberikan keturunan. ${ }^{3}$

Namun pada kenyataannya seorang suami tidak lagi mengikuti aturan yang telah ditetapkan oleh Undang-Undang. Di zaman ini kebanyakan suami yang melakukan pernikahan lagi tidak memiliki izin untuk melakukan perkawinan kedua oleh pihak pertama.

Pemalsuan terhadap sesuatu merupakan salah satu bentuk tindak pidana yang telah diatur dalam kitab undangundang hukum pidana (KUHP). Memang pemalsuan sendiri akan mengakibatkan seseorang atau pihak yang merasa dirugikan.

Hal inilah yang membuat pemalsuan ini diatur dan termasuk suatu tindakan pidana. Beberapa ketentuan yang termuat dalam kitab undangundang hukum pidana (KUHP) pemalsuan terdiri dari beberapa jenis yaitu sumpah palsu dan keterangan palsu, pemalsuan mata uang, uang kertas Negara dan uang kertas bank, pemalsuan surat dan juga pemalsuan terhadap materai dan merk.

Tindak Pidana yang sering terjadi adalah berkaitan dengan Pasal 263

3 Ibid hlm.7
KUHP (membuat surat palsu atau memalsukan surat); dan Pasal 264 (memalsukan akta-akta otentik) dan Pasal 266 KUHP (menyuruh memasukkan keterangan palsu ke dalam suatu akta otentik).

Dalam hukum di Indonesia pemalsuan terhadap sesuatu merupakan salah satu bentuk tindak pidana yang telah diatur dalam kitab undang-undang hukum pidana (KUHP). Memang pemalsuan sendiri akan mengakibatkan diatur dalam BAB XII Buku II KUHP, buku tersebut mencantumkan bahwa yang termasuk pemalsuan hanyalah berupa tulisan-tulisan saja, termasuk di dalamnya pemalsuan surat yang diatur dalam Pasal 266 Ayat (2) KUHP memalsukan akta-akta otentik dan Pasal 266 KUH Pidana (menyuruh memasukkan keterangan palsu ke dalam suatu akta otentik). ${ }^{4}$

Di Indonesia sering kita jumpai pola-pola serta perilaku kejahatan mulai dari yang dilakukan oleh kelas menengah ke bawah hingga kaum menengah keatas. Tentu saja dampak yang ditimbulkan oleh berbagai jenis dan macam perilaku menyimpang tersebut sangat meresahkan dan mengkhawatirkan sebagian besar masyarakat.

Kasus tentang pemalsuan surat sudah tidak dapat dipungkiri lagi bahkan terkadang seseorang melakukan sesuatu yang sakral pun seperti pernikahan tidak luput dari pemalsuan surat, seperti pemalsuan surat cerai yang dilakukan orang untuk menikah lagi tanpa harus mengurusi prosedurprosedur yang sulit untuk mendapatkannya.

Akibat dari perbuatan masyarakat yang tidak mau melakukan pernikahan

4 AdamiChazawi, 2002, Kejahatan Mengenai Pemalsuan, Jakarta : PT. Raja Grafindo Persada 
sesuai dengan prosedur yang ada maka menyebabkan akibat hukum sebagaimana yang telah terjadi pada kasus pemalsuan akta cerai, dimana kasus tersebut terdapat pada putusan pengadilan tingkat mahkamah agung dalam putusan Nomor: 439 K/PID/2017 terkait kasus pemalsuan akta cerai.

Berdasarkan latar belakang beberapa permasalahan tersebut, maka penulis ingin meneliti terkait kasus tersebut, sehingga menghadirkan pertanyaan-pertanyaan sebagai berikut :

1. Bagaimanakah penerapan Hukum terhadap Tindak Pidana Pemalsuan surat dalam putusan nomor: 439 K/PID/2017?

2. Bagaimanakah pertimbangan $\mathrm{Ha}-$ kim terhadap tindak pidana pemalsuan akta cerai dalam Putusan Nomor 439 K/PID/2017?

\section{B. PEMBAHASAN}

\section{Pengertian Tindak Pidana Pemalsuan Surat dan Pemalsuan Akta cerai Dalam Perkawinan}

\section{a. Pemalsuan Surat}

Pemalsuan surat dapat diartikan sebagai suatu perbuatan yang mempunyai tujuan untuk meniru, menciptakan suatu benda yang sifatnya tidak asli lagi atau membuat suatu benda kehilangan keabsahannya. Sama halnya dengan membuat surat palsu, pemalsuan surat dapat terjadi terhadap sebagian atau seluruh isi surat, juga pada tanda tangan pada si pembuat surat.

Pemalsuan surat diatur dalam Bab XII buku II KUHP, dari Pasal 263 sampai dengan Pasal 276 KUHP, yang dapat dibedakan menjadi 7 macam kejahatan pemalsuan surat, yakni:

1) Pemalsuan surat pada umumnya (Pasal 263 KUHP).
2) Pemalsuan surat yang diperberat (Pasal 264 KUHP).

3) Menyuruh memasukkan keterangan palsu ke dalam akte otentik (Pasal 266 KUHP).

4) Pemalsuan surat keterangan tabib/ dokter (Pasal 267 dan 268 KUHP).

5) Pemalsuan surat surat-surat tertentu (Pasal 269, 270, dan 271 KUHP).

6) Pemalsuan surat keterangan pejabat tentang hak milik (Pasal 274 KUHP).

7) Menyimpan bahan atau benda untuk pemalsuan surat (Pasal 275 KUHP)

Pasal 272 dan 273 telah ditiadakan berdasarkan S. 1926 No. 359 jo No. 429. Sedangkan Pasal 276 tidak memuat rumusan tindak pidana, tetapitentang ketentuan dapatnya dijatuhkan pidana tambahan terhadap si pembuat yang melakukan pemalsuan surat dalam Pasal 263 sampai dengan 268, berupa pencabutan hak-hak tertentu berdasarkan Pasal 35 Ayat (1) sampai (4). (Chazawi dan Ferdian, 2014: 136).

Menurut Andi Hamzah (2014:136) pemalsuan surat harus ternyata:

1) Diperuntukkan untuk bukti suatu fakta apakah menurut undangundang atau surat dari kekuasaan administrasi yang dikeluarkan berdasarkan wewenangnya atau juga dengan surat itu dapat timbul hak, suatu perikatan (verbintenis) atau pembebasan utang.

2) Dibuat palsu.

3) Pembuat mempunyai maksud untuk memakai sebagai asli dan tidak palsu atau menyuruh orang lain memakai.

4) Dengan pemikiran dengan itu dapat timbul kerugian.

\section{b. Unsur-Unsur Pemalsuan Surat}

Rumusan pasal tentang delik pemalsuan surat yang diatur dalam Pasal 263 KUHP, sebagai berikut :

(1) Barang siapa membuat surat palsu atau memalsukan surat yang dapat menimbulkan suatu hak, perikatan 
atau sesuatu pembebasan utang, atau yang diperuntukkan sebagai bukti daripada sesuatu hal, dengan maksud untuk memakaiatau menyuruh orang lain memakai surat tersebut seolah-olah isinya benar dan tidak dipalsu, diancam jika pemakaian tersebut dapat menimbulkan kerugian, karena pemalsuan surat, dengan pidana penjara paling lama enam tahun.

(2) Diancam dengan pidana yang sama, barangsiapa dengan sengaja memakai surat palsu atau yang dipalsukan seolah-olah sejati, jika pemakaian surat itu dapat menimbulkan kerugian.

Pada Pasal 263 ayat (2) bila dirinci, maka di dalam rumusan tersebut terdapat unsur-unsur sebagai berikut (Chazawi dan Ferdian, 2014: 159):

Unsur-unsur objektif:

a) Perbuatannya: /*Memakai

b) Objeknya:

1) Surat palsu

2) Surat yang dipalsu

c) seolah-olah asli;

d) Kesalahan: dengan sengaja.

Dari unsur-unsur delik pemalsuan surat tersebut, diketahui terdapat unsur objektifnya yaitu membuat surat palsu dan memalsukan sesuatu surat, dan antara kedua istilah tersebut terdapat pengertian yang berbeda.

Perbedaannya adalah bahwa membuat surat palsu maksudnya yaitu membuat sebuah surat sebagian atau seluruh isinya palsu, ini berarti bahwa sebelum perbuatan dilakukan tidak ada surat asli yang dipalsukan.

Misalnya mencetak suatu formulir yang lazim digunakan atau mengisi formulir yang sudah ada dengan menjiplak isinya sehingga seolah-olah isinya benar dan tidak palsu. Sedangkan pengertian "memalsukan surat" adalah perbuatan mengubah dengan cara bagaimana pun oleh orang yang tidak berhak atas sebuah surat yang berakibat sebagian atau seluruh isinya menjadi lain/berbeda dengan isi surat semula, hal ini berarti bahwa surat itu sebelumnya sudah ada, kemudian surat itu ditambah, dikurangi, atau dirubah isinya sehingga surat itu tidak lagi sesuai dengan asli.

\section{c. Definisi Perkawinan}

Menurut Undang-undang nomor 1 Tahun 1974 tentang Perkawinan di dalam pasal 1 dijelaskan bahwa;

"Perkawinan ialah ikatan lahir bathin antara seorang pria dengan seorang wanita sebagai suami isteri dengan tujuan membentuk keluarga (rumah tangga) yang bahagia dan kekal berdasarkan Ketuhanan Yang Maha Esa."

Di dalam pasal 2 undangan-undangan perkawinan selanjutnya menyebutkan mengenai sah atau tidaknya suatu perkawinan, karenasebagaimana kita ketahui masih sering terjadi kasus perkawinan yang tanpa memenuhi syarat sahnya suatu perkawinan.

Salah satupersoalan yang ada di dalam masyarakat yang berhubungan dengan masalah perkawinan adalah mengenai praktek pernikahan lebih dari sekali, yang mana didalam undangundang dijelaskan bahwa pria hanya boleh memiliki satu isteri dan juga sebaiknya, ketentuan tersebut yang kemudian melatar belakangi orang yang ingin memiliki isteri lebih dari satu untuk memalsukan asal-usul perkawinanAkta cerai.

Dalam Pasal 3 Undang-undang No. 1 Tahun 1974 dinyatakan, bahwa seorang pria hanya boleh memiliki satu istri dan demikian sebaliknya. Kalaupun pria tersebut hendak menikah lagi untuk yang kesekian kalinya, dalam Pasal 4 diatur, bahwa ada syarat bagi si pria untuk melakukannya, syarat tersebut antara lain harus mendapatkan izin pengadilan setempat, kemudi- 
an si istri tidak dapat melahirkan keturunan, tidak bisa melakukan kewajiban sebagai seorang istri, serta memiliki cacat badan atau penyakit yang tidak dapat disembuhkan. Kalaupun kemudian semua syarat itu terpenuhi, dalam Pasal 5 juga diatur bahwa pernikahan tersebut juga harus mendapat izin sang istri. Selain itu, ada kepastian bahwa suami mampu menjamin kebutuhan istri dan anak mereka, serta suami bisa berlaku adil kepada istri dan anak-anak mereka.

Persyaratan inilah yang harus dipenuhi oleh pria-pria yang akan menikah lagi. Namun karena dirasa sulit dan merepotkan, banyak pria yang demi untuk menikah lagi, pada akhirnya membuat keterangan palsu atau menikah kucing-kucingan.

\section{d. Konsekuensi Hukum Terhadap Pemalsuan Akta cerai}

Akta cerai merupakan surat/akta autentik yang dibuat berdasarkan keputusan hakim bagi mereka yang mengajukan gugatan perceraian di pengadilan. Artinya pengadilan merupakan lembaga yang memiliki kewenangan untuk membuat akta perceraian melalui putusan pengadilan. Maka selain melalui keputusan hakim dapat dinyatakan bahwa suatu akta cerai adalah palsu atau tidak sah.

Dalam Kitab Undang-undang Hukum Pidana (KUHP) pasal 263 ayat (1) juga telah diatur mengenai sanksi pidana terhadap pelaku pemalsuan surat dan akta autentik sebagaimana telah dijelaskan sebelumnya, artinya bahwa perbuatan memalsukan akta cerai merupakan suatu tindak pidana yang dapat dikenakan sanksi pidana.

Pada Buku II KUHP bab XIII mengatur lebih spesifik mengenai kejahatan terhadap asal-usul perkawinan, sebagaimana dijelaskan dalam pasal 280 yang menerangkan bahwa;

"Barang siapa mengadakan perkawinan, padahal sengaja tidak memberi tahu kepada pihak lain bahwa ada penghalang yang sah, diancam dengan pidana penjara paling lama lima tahun, apabila kemudian karena penggalang tersebut perkawinan kemudian dianggap tidak sah."

Dari isi rumusan pasal tersebut dapat kita jika kita kaitakan dengan tindakan pemalsuan akta cerai maka dapat kita simpulkan bahwa memalsukan akta cerai yang merupakan akata autentik dengan tujuan menutupi ataumemalsukan asalusul perkawinan maka terhadap orang tersebut dapat dikenakan sanksi pidana sebagaimana diatur dalam pasal 263 ayat (1) dan pasal 280 KUHP.

Selain dari itu terhadap suatu perkawinan yang tidak memenuhi syarat sahnya suatu perkawinan terutama yang berkaitan dengan pemalsuan akta cerai, maka bagi pihak korban atau pihak terkait dapat mengajukan pembatalan perkawinan sebagaimana diatur dan dijelaskan dalam pasal 22 dan pasal 24 undang-undang nomor 1 tahun 1974 tentang Perkawinan.

\section{Penerapan Hukum Dalam Tindak Pidana Pemalsuan Surat Dalam Putusan Nomor : 439 K/PID/2017.}

Penerapan hukum dapat pula dimaknai sebagai proses pemidanaan di dalam suatu perkara pidana, ada berbagai teori tentang pemidanaan yang dianut dan dipahami salah satu teori yang banyak dikenal adalah teori mutlak (absolute) yang mana dalam teori tersebut menyatakan bahwa pemidanaan adalah sebagai bentuk pembalasan atas suatu perbuatan pidan.

Ada pula teori relatif, teori ini berpendapat dasar hukum bukanlah pembalasan tetapi lebih kepada maksud/ tujuan hukuman, artinya tujuan ini mencari manfaat daripada hukuman. Beberapa doktrin mengajarkan yaitu diantaranya tujuan hukuman untuk mencegah keja- 
hatan baik pencegahan umum (Algemene Crime) maupun pencegahan khusus (Special Crime).

Selain itu, terdapat paham lain yaitu tujuan hukuman adalah untuk membinasakan orang yang melakukan kejahatan dari pergaulan masyarakat, tujuan pelaksanaaan daripada hukuman terletak pada tujuan hukuman.

Namun sejalan dengan perkembangan zaman lahir pula teori gabungan yang menyatakan bahwa Menurut teori ini dasar hukuman adalah terletak pada kejahatan sendiri yaitu pembalasan atau siksaan (teori mutlak) tetapi disamping itu diakuinya dasar-dasar tujuan daripada hukuman.

Penganut aliran ini diantaranya adalah Binding. Pembalasan sebagai asas pidana dan beratnya pidana tidak boleh melampaui pembalasan yang adil. Dalam ajaran ini diperhitungkan adanya pembalasan, prevensi general, serta perbaikan sebagai tujuan pidana.

Artinya jika disimpulkan dari ketiga teori tersebut maka tujuan dari suatu pemidanaan atau penerapan suatu hukum/aturan maka bukan hanya semata-mata hanya untuk membalas dendam atas suatu perbuatan pidana, melainkan demi tercapainya tujuan pembentukan hukum.

Dalam hal pidana pemalsuan surat hukum positif kita telah mengaturnya dalam Kitab Undang-undang Hukum Pidana (KUHP) yakni dalam pasal 263 ayat (1) dan ayat (2) dengan ancaman pidana maksimalnya adalah enam tahun penjara.

Dalam penelitian yang penulis lakukan terhadap putusan nomor : 439 $\mathrm{K} / \mathrm{PID} / 2017$. tentang tindak pidana pemalsuan akta cerai, dalam dakwaannya Jaksa Penuntut Umum mendakwa pelaku dengan dakwakan kumulatif yang mana pada dakwakan pertamanya pelaku dinyatakan melanggar ketentuan pasal 263 tentang memalsukan surat.
Kemudian di dalam dakwaan keduanya Jaksa Penuntut Umum mendakwa pelaku dengan pasal 280 KUHP tentang memalsukan asal-usul perkawinan. Namun di dalam tuntutannya Jaksa Penuntut Umum menyatakan bahwa terdakwa telah secara meyakinkan melanggar pasal 280 KUHP dan menuntut agar terdakwa dipidana dengan pidana penjara 1 tahun 6 bulan penjara.

Atas dasar dakwaan dan tuntutan yang diajukan oleh Jaksa Penuntut Umum serta memeriksa saksi-saksi dan bukti, hakim pengadilan negeri pada pokok putusannya menyatakan terdakwa Yefta Marsel Benyamin als. Moe telah terbukti secara sah dan meyakinkan bersalah melakukan tindak pidana "Pemalsuan Surat" dan MDB tindak pidana "Mengadakan Perkawinan Padahal Ada Penghalang Yang Sah.

Menjatuhkan pidana kepada Terdakwa oleh karena itu dengan pidana penjara selama 1 (satu) tahun dan menetapkan pidana tersebut tidak usah dijalani kecuali jika di kemudian hari ada putusan Hakim yang menentukan lain disebabkan karena Terpidana melakukan suatu tindak pidana sebelum masa percobaan selama 1 (satu) tahun dan 6 (enam) bulan berakhir.

Dalam memori Kasasinya Penuntut Umum pada pokonya menyatakan bahwa putusan hakim Pengadilan Tinggi yang menguatkan putusan pengadilan Negeri Soe tidak memberikan rasa keadilan kepada korban dan Penuntut Umum menganggap bahwa Judek facti keliru dalam menerapkan hukum dan tidak sesuai dengan ketentuan perundangundangan.

Adapun yang menjadi pokok putusan Majelis Hakim Mahkamah Agung dalam perkara pemalsuan surat/Akta cerai tersebut adalah menolak permohonan Kasasi Penuntut Umum dan memperbaiki putusan hakim Pengadilan Tinggi Kupang yaitu dengan menghukum terdakwa 
dengan pidana penjara selama 6 bulan, dengan perintah agar terdakwa tetap ditahan dalam rumah tahanan negara.

Menurut hemat saya secara yuridis baik pusan yang diputuskan oleh hakim Pengadilan Negeri maupun hakim Pengadilan Tinggi Soe telah sesuai dengan ketentuan perundang-undangan, meski memamg menurut pendapat pribadi penulis hukum yang diterapkan kurang memberikan rasa adil terhadap korban.

Sehingga putusan hakim Mahkamah Agung pada tingkat Kasasi yang memperbaiki putusan sebelumnya merupakan bentuk perwujudan hukum yang berusaha memberikan rasa keadilan bagi semua pihak. Jadi menurut pandangan penulis bahwa Judek yuris telah berhasil menerapkan hukum dengan bijaksana dan adil.

Dalam perkara pemalsuan akta cerai ini penulis justru berpendapat bahwa Penuntut Umum terkesan kurang maksimal dalam upaya menerapkan hukum terhadap pelaku, hal tersebut dapat kita lihat dari tuntutan pidana Jaksa Penuntut Umum yang terlalu rendah yakni hanya 1 tahun 6 bulan penjara, padahal ancaman pidana maksimal dalam pasal 263 KUHP adalah 6 tahun penjara dan pada pasal 280 KUHP ancaman pidana maksimalnya adalah 5 tahun penjara.

\section{Pertimbangan Hakim terhadap Tindak Pidana Pemalsuan Akta Cerai dalam Putusan Nomor : 439 K/PID/2017}

Terdakwa Yefta Marsel Benyamin yang masihterikat pernikahan dengan seorang perempuan bernama Astrit Aulin Cendana Wangi Nalenan (korban) sesuai Surat Nikah yang dikeluarkan oleh Gereja Masehi Injili di Timor Nomor: 16/GLN/ 2000 tanggal 24 November2000 dan Surat Kutipan Akta Perkawinan Nomor: 1007/ DIPENDUK.KK/2000 tanggal 4 November 2000 dan telah memiliki 2 (dua) orang anak, menjalinhubungan dengan Marleni Dince Benu alias Dince selanjutnya akan disebut (MDB) (sudah menikah dan mengatakan sudah bercerai namun tidak bisa membuktikan Surat Perceraian dari Pengadilan Agama)

Terdakwa dan MDB bersepakat melakukan pernikahan dengan cara mencari orang yang bisa mengurus pernikahan mereka. Kemudian Terdakwa menghubungi Yulius Benu atau (YB) untuk mencarikan gereja yang melakukan pernikahan massal, YB kemudian mendaftarkan Terdakwa dan MDB di gereja pada Desa Kelle, namun oleh pihak gereja menolak karena Terdakwa dan MDB tidak bisa menunjukkan Surat Rekomendasi dari gereja asal.

Kemudian YB mendaftarkan Terdakwa dan MDB di Gereja Esamatsio Nunusunu melalui Majelis Rayon yakni Piter Kmio yang mana kebetulan di gereja tersebut akan mengadakan pernikahan massal pada tanggal 25 Oktober 2015. Kemudian pada tanggal 24 Oktober 2015, Terdakwa dan sdri. Marleni Dince Benu al ias Dince datang ke Gereja Esamatsio Nunusunu untuk mengikuti pengembalaan bersama pasangan 3 (tiga) calon pengantin lainnya.

Pada saat Pendeta Agneta Ndaomanu Lewar menanyakan surat rekomendasi dari gereja asal, Terdakwa dan MDB berbohong dengan mengatakan bahwa surat rekomendasi tersebuttertinggal di rumah Kelle sehingga pada saat itu Terdakwa menyuruh YB pergi mengambil surat tersebut, namun pada saat YB kembali ke gereja YB mengatakan bahwa Surat Rekomendasi tersebut tidak diketemukan.

YB berusaha meyakinkan bahwa Terdakwa dan MDB resmi telah bercerai di Pengadilan Negeri, namun melihat hal tersebut Pendeta Agneta Ndaomanu Lewar menjadi ragu untuk memberkati pernikahan Terdakwa dan MDB, kemudian Terdakwabersama MDB bersedia membuat surat pernyataan menyatakan 
bahwa Terdakwa dan MDB sudah tidak ada terikat pernikahan dengan orang lain.

Terdakwa dan MDB juga membuat surat keterangan palsu berupa surat pernyataan bersedia digugat secara hukum oleh pihak lain apabila masih memiliki ikatan pernikahan dengan orang lain, sehingga dengansurat palsu tersebut akhirnya Terdakwa dan MDB dapat diberkati menjadi suami isteri yang sah menurut gereja.

Akibat perbuatan Terdakwa tersebut korban selaku isteri sah dari Terdakwa merasa dirugikan dan melaporkan perbuatan Terdakwa kepada pihak Kepolisian, atas laporan tersebut polisi kemudian melakukan penangkapan dan selanjutnya melakukan penahanan terhadap terdakwa.

Bahwa yang menjadi sumber pertimbangan Majelis Hakim Mahkamah Agung dalam kasus tindak pidana pemalsuan akta cerai adalah dakwaan serta tuntutan Jaksa Penuntut Umum, kemudian pertimbangan dan keputusan hakim Pengadilan Negeri dan keputusan hakim Pengadilan Tinggi Soe.

Seluruh bukti dan fakta-fakta yang diperoleh di dalam proses persidangan juga merupakan bagian yang dijadikan dasar pertimbangan Majelis Hakim Mahkamah Agung dalam memeriksa perkara tersebut, termasuk memori banding dan memori kasasi yang diajukan oleh Jaksa Penuntut Umum.

Dalam Pertimbangannya Majelis Hakim Mahkamah Agung menyatakan bahwa alasan permohonan Kasasi Penuntut Umum tidak dapat dibenarkan karena putusan hakim Pengadilan Tinggi Soe yang menguatkan putusan Pengadilan Negeri Soe yang menyatakan bahwa terdakwa telah terbukti secara sah dan meyakinkan bersalah melakukan tindak pidana pemalsuan surat dan melakukan perkawinan padahal ada penghalang yang sah, tidak salah dan sudah sesuai ketentuan perundang-undangan.
Menurut Pertimbangan Majelis Hakim bahwa berat ringannya pidana yang dijatuhkan pada prinsipnya merupakan wewenang Judex Facti, akan tetapi bila ada fakta relevan yang memberatkan atau meringankan terdakwa belum dipertimbangkan Judex Facti atau Judex Facti tidak cukup mempertimbangkan mengenai hal tersebut, Mahkamah Agung dapat memperbaiki pidana yang dijatuhkan kepada Terdakwa.

Namun dalam perkara ini Judex Facti sudah cukup mempertimbangkan mengenai hal-hal yang memberatkan dan meringankan sesuai Pasal 197 Ayat (1) huruf f KUHAP.

Mengenai alasan kasasi Penuntut Umum berkenaan dengan penilaian hasil pembuktian yang bersifat penghargaan tentang sesuatu kenyataan. Hal tersebut tidak dapat dipertimbangkan dalam pemeriksaan tingkat kasasi, karena pemeriksaan tingkat kasasi hanya berkenaan dengan tidak diterapkannya suatu peraturan hukum atau peraturan hukum tidak diterapkan sebagaimana mestinya, atau apakah cara mengadili tidak dilaksanakan menurut ketentuan undangundang, dan apakah Pengadilan telah melampaui batas wewenangnya.

Pertimbangan lainnya yaitu, bahwa penjatuhan pidana terhadap terdakwa perlu diperbaiki, oleh karena putusan yang dijatuhkan Judex Facti kurang mempertimbangkan rasa keadilan bagi saksi korban dan Gereja Esamatsio Nunusunu, khususnya bagi Pendeta Agneta Ndaumanu Lewar, S.Th., karena perbuatan Terdakwa tersebut telah menyebabkan Pendeta Agneta Ndaumanu Lewar, S.Th., mendapat teguran dari Ketua Sinode GMIT Kupang, dan selain itu sebagai efek jera bagi terdakwa dan masyarakat lainnya agar tidak melakukan perkawinan dengan memalsukan surat dan ada perkawinan lain yang sah yang menjadi penghalang bagi perkawinannya tersebut. 
Berdasarkan pertimbangan tersebut di atas maka permohonan Kasasi Penuntut Umum harus ditolak, namun demikian amar putusan Pengadilan Tinggi Kupang Nomor 93/PID/2016/PT.KPG, tanggal 17 Oktober 2016 yang mengguatkan putusan Pengadilan Negeri Soe Nomor 49/Pid.B/2016/PN.Soe, tanggal 16 Juni 2016, perlu diperbaiki sekedar mengenai penjatuhan pidana kepada terdakwa.

Perubahan yang dimaksud adalah keputusan hakim Pengadilan Tinggi yang menguatkan putusan hakim Pengadilan Negeri Soe yang menjatuhkan pidana 1 (satu) tahun penjara dan terdakwa tidak perlu menjalankan pidana tersebut, dan hanya menetapkan masa percobaan selama 1 (satu) tahun 6 (enam) bulan. Keputusan tersebut dirubah menjadi pidan penjara selama 6 bulan dengan perintah agar terdakwa tetap berada di dalam rumah tahanan Negara.

\section{PENUTUP}

Penerapan hukum yang dijatuhkan kepada terdakwa sudah sesuai dengan undang-undang yang berlaku di negara Indonesia. Walaupun vonis yang dijatuhkan di pengadilan negeri oleh jaksa penuntut umum cukup dibilang minim dikarenakan memalsukan surat perceraian yang mengakibatkan ruginya hak-hak korban (istri) dengan maksimal hingga 5 tahun tetapi hanya divonis 1 tahun 6 bulan. Dalam putusan hakim Pengadilan negeri dan pengadilan tinggi kurang memberikan rasa adil kepadakorban sehingga putusan mahkamah agung menurut penulis cukup adil dikarenakan agar terdakwa tetap ditahan dalam tahanan negara.

Pertimbangan hakim dalam menetapkan hukuman bagi terdakwa menurut penulis sudah sesuai dikarenakan per- timbangan hakim yang memperbaiki putusan-putusan sebelumnya yaitu putusan pengadilan negeri dan putusan pengadilan tinggiyang dirasa kurang adil bagi korban.

Untuk masyarakat agar tidak melakukan tindakan pemalsuan surat dikarenakan dapat dikenakan sanksi pidana sebagaimana yang sudah di atur dalam KUHP. Untuk Hakim agar dapat memutuskan lebih adil dalam mempertimbang putusan.

\section{DAFTAR PUSTAKA}

\section{Buku/Literatur}

Chazawi Adami, 2002, Kejahatan Mengenai Pemalsuan, Jakarta : PT. Raja Grafindo Persada Sudarsono, Hukum Perkawinan Nasional, Rineka Cipta, Jakarta,2010

Tarmizi M. Jakfar, Poligami dan Talak Liar dalam Perspektif Hakim Agama di Indonesia, Banda Aceh: Ar-Raniry Press, 2007

\section{Perundang-Undangan}

Kitab Undang-undang Hukum Pidana

Indonesia, Undang-Undang Nomor 1 Tahun 1974 Tentang Perkawinan 